This is the peer reviewed version of the following article:

Ágnes Nagy, Tivadar M. Tóth, Balázs Vásárhelyi, Tamás Földes (2013): Integrated core study of a fractured metamorphic HC-reservoir; Kiskunhalas-NE, Pannonian Basin.

Acta Geodaetica et Geophysica, March 2013, Volume 48, Issue 1, pp 53-75

DOI: 10.1007/s40328-012-0008-y

The final publication is available at Springer via: http://dx.doi.org/10.1007/s40328-012-0008-y

\title{
Integrated core study of a fractured metamorphic HC-reservoir;
}

\section{Kiskunhalas-NE, Pannonian Basin}

\section{ÁGNES NAGY ${ }^{1}$, TivadAR M. TÓTH ${ }^{1}$, BALÁZS VÁSÁRHELYI ${ }^{2}$, TAMÁS FöLDES ${ }^{3}$}

1 University of Szeged, Department of Mineralogy Geochemistry and Petrology, H-6701, Szeged P. O. Box 651, mtoth@geo.u-szeged.hu, agnes.nagy@geo.u-szeged.hu

2 Department of Structural Engineering, Pollack Mihály Faculty of Engineering, University of Pécs, vasarhelyib@gmail.com

3 Kaposvár University, Institute of Diagnostic Imaging and Radiation Oncology, t.foldes@ t-online.hu

\section{Abstract}

The petrologic interpretation of the coexisting lithologies in the KIHA-NE metamorphic block suggests that two of the four rock units may have a significant role in the migration and/or storage of hydrocarbons. The strongly sheared mylonite samples exhibit remarkable fracture systems with clear evidence of one-time oil migration. In the course of the integrated core study, in addition to the petrological methods, 3D CT scans and destructive and non-destructive rock mechanical treatments were fulfilled on representative samples and evaluated. On the basis of the results we can state that the petrologically different rock types have remarkably different brittle behaviours. The orthogneiss mylonite is characterised by moderate anisotropy and fracture tendency. However, the fractal dimension and cumulative fracture length values do not suggest the formation of complicated and connected fracture systems. High anisotropy and a large and possibly communicating fracture system characterise the graphitic gneiss mylonite, achieved by a much lower work investment than for any other rock type.

Keywords: fractured metamorphic reservoir, mylonite, rock mechanical parameters, X-ray Computed Tomography (CT),

\section{Introduction}

The fracture system of hard rock bodies serves as migration pathways and/or storage for various fluids of industrial importance: hydrocarbons, geothermal and drinking water. A single crystalline basement block may be characterised by different rock types with different rheology parameters and structural evolutions and thus the capacity for brittle deformation may be extremely heterogeneous inside the complex. Consequently, blocks with significantly different kinds of fracture systems with diverse characteristics may evolve in the same reservoir. To understand the 
behaviour of these fluid reservoirs, knowledge of their petrology is necessary and in this regard well-core investigations are among the most important facets. Because of the small number of cores compared with the number of wells, it is important to obtain as much information as possible from each sample. For efficiency it is desirable to integrate the results of the various core examination approaches in a coherent system. The main subjects that should be addressed are: a complex petrographic analysis, microstructure analysis, rock mechanics and an evaluation of fracture patterns both of natural and provoked origin.

The Pannonian Basin is situated inside the Alpine-Carpathian-Dinaric orogenic belt. Its crystalline basement is extremely complex, both petrologically and structurally. As a consequence of the complicated subsidence history of the basin during the Neogene (e.g., Tari et al., 1992, Horváth, 1995; Csontos and Nagymarosy, 1998; Horváth et al., 2006) uplifted metamorphic basement highs also formed (e.g., Tari et al., 1992; M. Tóth and Zachar, 2006; Zachar et al., 2007; M, Tóth et al., 2009). These blocks serve as excellent fractured reservoirs of hydrocarbon (e.g., M. Tóth et al., 2002; M. Tóth et al., 2004; Schubert et al., 2007) and thermal water (e. g., Stegena et al., 1992) and make the understanding of this region especially important. The aim of the present study is to understand the lithologies and their reservoir properties of a basement fluid reservoir (example of KIHA-NE) using the method of an integrated core examination. The region of the KiskunhalasNE (KIHA-NE) basement high is one of the most remarkable fractured metamorphic HC-reservoirs in the Pannonian Basin.

\section{Geological background}

The Pannonian Basin is a complicated mosaic of blocks with incompatible evolutions, because of its complex, multistage tectonic history (D. Lörincz, 1996). The basement is composed mainly of Variscan age crystalline rocks (Szederkényi, 1984; Lelkes-Felvári et al., 2003; LelkesFelvári and Frank, 2006). It underwent large scale extension during the early Jurassic (Csontos et al., 1992; Haas and Péró, 2004) and nappe formation in the Cretaceous (Tari el al., 1999). During the Neogene basin subsidence, deep sub-basins evolved surrounded by basement highs. The metamorphic basement of the Pannonian Basin can be investigated by several borecores, which penetrated these uplifted regions.

The Kiskunhalas-NE Field is situated south of the Mid-Hungarian tectonic zone that separates the Tisza Unit from the ALCAPA Unit (Csontos and Nagymarosy, 1998). According to recent interpretations, the study area is located close to the assumed front of the Codru Nappe, which formed due to Cretaceous tectonic activity. There are two neighbouring metamorphic domes that have been previously studied; the petrologically well-known metamorphic block Jánoshalma 
High (JH) to the SW and the less well-known Tázlár (T) to the NE (Fig. 1).

According to the small number of papers that have previously dealt with the KIHA-NE Field: gneiss, micaschist, amphibolite, different mylonite types, migmatite and a low-grade phyllite variety predominate in the study area with an unknown structural arrangement (Cserepes, 1980; Cserepes-Meszéna, 1986; T. Kovács and Kurucz, 1984). T. Kovács (1973) suggests that in relation to the general amphibolite facies metamorphism of Variscan age, at certain places migmatites and diatexites formed. In the course of the following retrograde metamorphism, mylonite, chlorite schist and sericite schist evolved (Árkai, 1991). Árkai (1978, 1991) suggests that the protolith of the phyllites was marly sediment formed under reductive conditions. Using illite crystallinity indices it is thought to have undergone a very low-grade metamorphism with a peak of about $270-300{ }^{\circ} \mathrm{C}$ (Árkai, in Cserepes-Meszéna, 1986). Árkai (1991) supposes that the low-grade phyllite represents an exotic nappe and consequently its contact to other rock types must be tectonic. Geochemical data infer weathering of the phyllite body under surface conditions.

The latest examinations (Nagy and M. Tóth, 2012) based on the macroscopic, microscopic and thermometric studies of borecore samples identified four main rock types. The ideal rock column was defined using all available borecore specimens. The following petrological characterisation is after Nagy and M. Tóth (2012). At the lowermost structural position an unaltered orthogneiss (OG) is characteristic (Fig. 2/a). This gneiss variety contains amphibolite xenoliths and was intruded by mica-poor post-metamorphic granitoid intrusions. From the textural features and the mineral assemblage the orthogneiss is identical to that described in the neighbouring Jánoshalma high by Zachar and M. Tóth (2004). It exhibits a two-stage evolution with very poorly constrained metamorphic conditions of $T_{1} \sim 700-850{ }^{\circ} \mathrm{C}$ at $P_{1}<0.65 \mathrm{GPa}$, and $T_{2}<580$ ${ }^{\circ} \mathrm{C}$. From a geological reservoir point of view, this block has only minor significance because of the small amount of natural fractures. The next lithological zone upwards consists of orthogneiss mylonite (OGM) (Fig. 2/b) exhibiting textural features of ductile deformation, which took place in an extensional regime (C/S fabric, apatite bookshelf, plastically deformed quartz grains). On the basis of the biotite-muscovite-feldspar-quartz mineral assemblage and the relic magmatic textures, like mirmekitic feldspar grains and the idiomorphic habit of accessory phases (zircon), the protolith of the mylonite prior to ductile deformation should have been the lowermost orthogneiss. Some gneiss mylonite samples are locally oil spotted suggesting that the generally moderately fractured OGM zone may be important from a geological reservoir point of view. Further upwards, mylonites occur with extensional fabric elements (C/S fabric, apatite bookshelf, boudinaged clasts, deformed quartz grains) similar to those that characterise the OGM unit. This zone however, exhibits significantly different mineralogy. The diagnostic phases of the orthogneiss are missing (biotite) or play only a subordinate role (feldspar), while graphite, pyrite and carbonate become characteristic 
phases. According to the results of different thermometers that use Raman spectral parameters of carbonaceous material (Beyssac et al., 2002; Rahl et al., 2005; Aoya et al., 2010), the peak metamorphism of this graphitic gneiss mylonite zone (GGM) (Fig. 2/c) was $T$ of $410 \pm 45^{\circ} \mathrm{C}$. The carbonate minerals occur in small-sized nests in the matrix, which locally could have been dissolved. Strongly fractured, locally brecciated borecore samples of this rock unit are often oil spotted. Estimations of the deformation temperature for both mylonitic rocks give approximately $T_{\text {def }} \sim 455{ }^{\circ} \mathrm{C}$ (using the quartz suture thermometer of Kruhl and Nega, 1996). The uppermost member of the rock column is graphitic carbonate phyllite (Fig. 2/d) represented by just a small number of samples. This rock unit can be characterised by $T$ of $370 \pm 15^{\circ} \mathrm{C}$, estimated by the Raman spectroscopy carbonaceous material thermometer. This rock type is not mylonitic.

Results of previous and current geothermometric calculations suggest that there is an approximately $200{ }^{\circ} \mathrm{C}$ difference between the peak metamorphic temperatures of the two extreme lithologies (orthogneiss and carbonate phyllite) in the rock column. This means a 5-10 km difference in formation depth depending on the one-time geothermal gradient. This result, together with presence of the extensional mylonites, implies that the study area evolved in an extensional stress regime following the thermal peak; blocks of different metamorphic conditions became juxtaposed along a shear zone at a depth corresponding to $\sim 455{ }^{\circ} \mathrm{C}$ (Nagy and M. Tóth, 2012). The entire rock column behaved uniformly during the following tectonic development; at shallower positions it deformed in a brittle way. Nevertheless, the different lithology types not necessarily fractured in a same extent and mode.

The petrologic interpretation of the coexisting lithologies in the KIHA-NE metamorphic blocks suggests that two of the four rock units may have a significant role in migration and/or storage of hydrocarbons. The strongly sheared mylonite samples exhibit remarkable fracture systems with clear evidence for one-time oil migration. In the course of the rock mechanical investigations we focus on these two mylonitic rock types.

\section{Methods}

In the course of the integrated core study, the following list of examinations was fulfilled and evaluated:

1) Identification and classification of the rock specimens by conventional petrographic and petrological methods; macroscopic and microscopic description, interpretation of the microtextures and geothermobarometric calculations. Using all these data the metamorphic and structural evolution of the investigated area can be sketched out and a reliable geological framework model can be established. 
2) Preparation of representative samples from the important lithologies with standardised circumstances for rock mechanical treatment. Careful selection of samples without fractures is essential, because even closed or cemented natural fractures may significantly modify the rock mechanical behaviour of the rock matrix.

3) 3-dimensional scan of the specimens with Computed Tomography (CT) using standardised setup.

4) Destructive and non-destructive rock mechanical treatment on the intact specimens.

5) 3D CT scan of the treated specimens.

6) Evaluation of rock mechanical data and the CT images using image analysis methods and statistical data processing.

Following several experiments (not detailed here) settings for all steps were optimised and the above list was used as a standard routine afterwards.

\subsection{X-ray Computed Tomography (CT)}

\subsubsection{Overview of the X-ray Computed Tomography}

X-ray CT allows visualisation of the internal structure of objects by mapping the variation of the X-ray attenuation within the object. The resulting image displays the differences in density according to the X-ray attenuation law; the smaller the attenuation coefficient of the body, the darker the image. CT provides three-dimensional information about the heterogeneities within the samples in relation to the density and chemical composition of the object and the energy of the incident X-ray beam. This non-destructive method allows the detection of boundaries between phases and materials, or discontinuities (pores, fractures) of the samples. Furthermore, the data are digital, which aids easy quantitative analysis and the interpretation by image processing software (Ikeda et al., 2000; Ketcham and Carlson, 2001; Mees et al., 2003). The radiological density is expressed in Hounsfield units (HU), which is a dimensionless number normalised by the linear attenuation coefficient of water (HU = -1000 for air, $\mathrm{HU}=0$ for water, Hounsfield, 1973).

\subsubsection{CT applications in geology}

CT was developed for medical applications and was later extended and widely-adopted in many industrial fields. The first geological application was inspired by the fact that CT could acquire interior information from irreplaceable specimens in a non-destructive manner. The early application and subsequent discovery of the further potential of CT is thoroughly discussed by Ketcham and Carlson (2001) and Mees et al. (2003).

Before the application of CT, the most widely available examination of rock samples was in 2D. Although there were some circumstantial and time-consuming methods to get $3 \mathrm{D}$ information about the structural or textural features of a sample, like using successive digitised images acquired 
by serial thin sectioning or lapping (Bryon et al., 1995; Cooper and Hunter, 1995; Marschallinger, 1998), or by partial melting experiments (Philpotts et al., 1998), these were not applicable to all rock types (Ikeda et al., 2000). The propagation of the CT method in geology provided the opportunity for visualisation and quantitative textural analysis of igneous (e.g., Carlson et al., 2000; Ikeda et al., 2000) and metamorphic rocks (e.g., Denison et al., 1997; Denison and Carlson, 1997; Ikeda et al, 2000; Ketcham, 2005; Huddlestone-Holmes and Ketcham, 2010).

In the case of conventional reservoir lithologies (sedimentary rocks), CT was used to determine the porosity of the rocks and investigate the fluid flow in the samples (e.g., Wellington and Vinegar, 1987; Van Geet et al., 2000; Földes et al., 2004). In non-conventional (fractured hard rock) reservoirs, the porosity relates to the fracture properties of the rock, which can also be investigated by CT methods. A combination of breaking tests and CT scanning was applied by Raynaud et al. (1989) among others. They deformed and fractured four different rock types in a triaxial cell and then compared the experimental results with the radiological density data. Vinegar et al. (1991), in addition to strain localisation examinations on sandstone, observed the correlation between Hounsfield units and the porosity and grain density of each section of the samples. Bésuelle et al. (2003) also crushed the samples in a triaxial cell to investigate the strain localisation and then quantitatively characterised the damage state in thin sections. Other authors have examined faults in sandstone (Antonellini et. al, 1994) or in granite (Kawakata, 1999) with CT.

This study aims to obtain images of the internal structure and the provoked fractures in the specimens on a millimetre scale and therefore, a conventional medical CT was the appropriate technique for scanning (Mees et al., 2003). The measurements were carried out on the S40 spiral Siemens Somatom Sensation CT scanner in the Institute of Diagnostic Imaging and Radiation Oncology, University of Kaposvár, Hungary. This is high-performance equipment with a dual-focus $\mathrm{X}$-ray tube with rotating anode and Xe detectors. The voltage and current of the X-ray tube were $140 \mathrm{kV}$ and $189 \mathrm{~mA}$, respectively. The X-ray exposure time for each slice was $1.5 \mathrm{~s}$ and the thickness of each slice was $1 \mathrm{~mm}$. The voxel size was $0.25 \times 0.25 \times 1 \mathrm{~mm}$.

\subsection{CT data processing}

The HU values of the CT datasets are proportional to the density of the scanned object. These numerical data can be handled by statistical methods that give an opportunity to compare the density conditions of the intact and crushed samples. For this purpose we calculated the standard descriptive statistical parameters, mean, modus and standard deviation of the HU data, both for the whole 3D data blocks and for each slice independently, in order to understand the response of the different lithologies to stress. When evaluating the CT data only those parts of the images that related to the rock material were taken into consideration. Background (air) appears in the pixels of 
wider fractures in the crushed samples and was filtered out by choosing an appropriate threshold value. During the petrographic image analysis the Fiji (ImageJA 1.45i) software package was used.

To characterise quantitatively the ability for fracturing, a size-independent parameter should be defined. For this process CT images of the crushed samples were evaluated. The most straightforward way to measure the amount of fractures is to count pixels that contain provoked discontinuity. This value normalised by the area of the studied CT section results in a parameter called cumulative fracture length (CFL). It is rather similar to the widely-used fracture intensity measured by $\mathrm{m} / \mathrm{m}^{2}$ (e.g., Liu et al., 2004; Ortega et al., 2006).

Nevertheless, explicit selection of those pixels that represent cracks in the CT image is rather difficult because of the wide spectrum of gray colours of the host rock itself. Therefore, the original data set should be treated with image analysis tools (brightness, contrast and intensity) to transform it to a black and white image, where one extreme (e.g. black) represents the fractures, whilst the other is for the rock material. For this process the Osiris 4.19 software was used.

The complexity of the fracture network can be characterised by numerous quantitative parameters, among which the fractal dimension of the pattern is a widely-used choice (e.g., Barton and Larsen, 1985; Hirata, 1989; Matsumoto et al., 1992; Tsuchiya and Nakatsuka, 1995). In contrast to any other possible parameter, fractal dimension not only determines fracture density, but also the measure of scale independency of the network. Fractal dimension (D) values for each treated sample were determined by the common box-counting method (e.g., Barton, 1995; Li et al., 2009) on representative $\mathrm{CT}$ sections parallel to the sample axis.

\subsection{Rock mechanical tests}

In the course of rock mechanical tests we investigated the mechanical behaviour of the fracture free rock body. Careful sample selection and the standardised laboratory measurements should provide a reliable sample set. Through the sample selection procedure we chose intact borecores, which were not affected by natural brittle deformation events. Following pre-selection using a hand lens and binocular microscopy and after appropriate internal structures had been tested by evaluating CT images, non-destructive and destructive rock mechanical methods were applied.

The aim in cutting samples was the creation of regular cylindrical shapes with the standard 2:1 (axis:diameter) size and $50 \mathrm{~mm}$ diameter. In a few cases, when borecore size did not allow cutting standard sized samples, rock mechanical data were converted using the suggestions of the ISRM (ISRM, 2006). The American Society for Testing and Materials (ASTM) size effect corrections (ASTM, 2004) were used for the compressive strength. When possible, more than one sample was taken from a single borecore. Considering the intensely deformed lithology, samples were prepared both parallel and perpendicular to the dominant foliation from the same lithologies. 
In total, 22 samples were prepared from the three basic lithologies representing 9 borecores from the KIHA-NE Field (Table I.).

\subsubsection{Non-destructive tests}

After cutting the samples, their ultrasonic wave velocity was measured in accordance with the suggestion of the International Society for Rock Mechanics (ISRM, 2006).

\subsubsection{Destructive tests}

The most common approach to study the mechanical properties of rocks is by using an unconfirmed compressive test. If the lateral surface of the rock is traction-free, the configuration is referred to as uniaxial compression $\left(\sigma_{1}>0, \sigma_{2}=\sigma_{3}=0\right)$.

Using this configuration, the uniaxial strain $(\varepsilon)$ depends upon uniaxial stress $(\sigma)$ and can be measured. If $\sigma$ is plotted against $\varepsilon$ given the stress-strain curve, the point at which it reaches the maximum stress value is the uniaxial compressive strength $\left(\sigma_{c}\right)[\mathrm{MPa}]$ and this point marks the transition from ductile to brittle behaviour. From the slope of a stress-strain curve at $50 \%$ of the ultimate stress, Young's modulus (elasticity modulus $(E)[\mathrm{GPa}]$ ) can be experimentally determined; the elastic modulus is calculated at $50 \%$ of the ultimate strength, according to the ISRM (2006). This material property describes well the rigidity of the samples. The Poisson's rate value $(v)$ is the ratio of the axial and lateral strains. Most rocks have Poisson's ratio values ranging between 0.2 and 0.4. A perfectly incompressible material deforms elastically at small strains and would have a Poisson's ratio of exactly 0.5 (Jaeger et al., 2007). Due to the different rock samples and the uncertainty of the measuring methods, this material constant could be not determined absolutely (Gercek, 2007). Destruction work (or strain energy $-W_{d}$ ) can be calculated from the measured stress-strain curves. It is equal to the area under the measured curve and it is equal to the energy necessary for breaking the rock.

Several characteristic stress levels can be determined through laboratory tests that are substantial in understanding the failure (damage) process of brittle rocks during compression. The complete axial stress-strain relations by Cai (2010) and Martin (1993) illustrated on Fig. 3. The symbols are the following:

- $\sigma_{\mathrm{cc}}$ is the crack closure stress level,

- $\sigma_{\mathrm{ci}}$ is the crack initiation stress level,

- $\sigma_{\mathrm{cd}}$ is called the crack propagation stress level. This latter parameter is close to the longterm rock strength (Martin, 1993; Cai, 2010).

The above three stress levels, i.e., $\sigma_{\mathrm{ci}}, \sigma_{\mathrm{cd}}$, and $\sigma_{\mathrm{cc}}$, show important stages in the macroscopic damage process of intact rocks. Crack initiation starts at stress levels of about $1 / 3$ to $2 / 3$ times the 
peak uniaxial load $\left(\sigma_{f}\right)$ for most brittle rocks (Bieniawski, 1967; Cai et al., 2004).

The crack initiation stress $\left(\sigma_{\mathrm{ci}}\right)$ can be identified on intact rocks in the course of laboratory tests by the onset of stable crack growth or dilatancy. This can be defined from the stress-volumetric strain curve as the point of the departure of the volumetric strain observed at a given mean stress from that observed in uniform loading to the corresponding pressure (Bieniawski 1967). In the case of a uniaxial (or triaxial) test, the volumetric strain $\varepsilon_{\mathrm{v}}$ is defined by:

$$
\varepsilon_{v}=\varepsilon_{a}+2 \varepsilon_{l}
$$

where: $\varepsilon_{\mathrm{a}}$ and $\varepsilon_{1}$ are the axial and lateral strains, respectively. The crack volumetric strain $\varepsilon_{\mathrm{cv}}$ is defined by (Martin, 1993), so that:

$$
\varepsilon_{c v}=\varepsilon_{v}+\frac{1-2 v}{E} \sigma_{a}
$$

where: $\sigma_{\mathrm{a}}$ is the axial stress, E is the Young's modulus, and $v$ is Poisson's ratio. As the Fig. 3 illustrates, both the volumetric strain and the crack volumetric strain plots can be used to determine the crack initiation stress level $\left(\sigma_{\mathrm{ci}}\right)$. This parameter can also be identified as the point where the volumetric strain starts to differ from the straight line of the elastic deformation stage (stage II), or the crack volumetric strain deviates from zero, as shown in Fig. 3.

Microscopic observations indicate that newly generated cracks are tensile in nature, generated by extension train, and mostly aligned in the same direction as the maximum compressive stress. After crack initiation, the propagation of the microcracks is a stable process, which means that the cracks only extend by limited amounts in response to given increments in stress (Cai, 2010).

Unfortunately, we have no opportunity to measure the Acoustic Emission (AE), so the data were determined only the measured stress and strain parameters.

Destructive tests were carried out in the Rock Mechanics Laboratory at the Budapest University of Technology and the Economics. Under the experimental procedure the following conditions were used: periodic loading-unloading velocity, gradually grown amplitude and 3-4 loading cycles. The loading cycles were designed so that the samples were charged over the damage limit, but before fracturing, that is the hypothetic main fracturing zone. The following parameters were determined in the above detailed theoretical background: ultrasonic wave velocity, compressive strength, elastic (Young's) modulus, Poisson's ratio and destructive work.

\subsection{Statistical methods for data processing}

In the course of the rock mechanical measurements and image analysis of CT scans, several numerical data were determined. This data set concludes the mechanical behaviour of the most essential rock types of the KIHA-NE Field. As reservoir properties in a hard rock reservoir are 
basically determined by fracture network characteristics, the question to be addressed by the statistical analysis of this data set, was whether or not known rock types behave differently concerning their rock mechanical parameters. To test how well they can be distinguished, discriminant function analysis is a suitable method. The calculations were performed in the computer program SPSS 18.

\section{Results}

\subsection{Results of CT measurements}

The size of the samples did not cause abnormal radiation absorption. CT images following rock mechanical treatment exhibit significantly different fracture patterns for the three studied lithologies and also sample orientation (Fig. 4.). For samples perpendicular to the foliation, markedly fewer fractures appear compared with parallel samples in all cases. Moreover, GGM tends to break more intensively than the two other rock varieties.

\subsection{Results of CT data processing}

For the quantitative comparison of the intact and crushed rock matrices, the HU of the CT images were used. The means and the modi of the whole scans and individual slices, as well as the HU histograms (Fig. 5/a) of the samples were investigated.

The characteristic CT scan histograms of the samples are skewed, because the rock characteristic densities appear in the determined rock material interval. Therefore, the mean of the HU values are less useful than their mode. The intact samples cannot be separated by their HU distributions. They have quite similar shapes (Fig.5/a); narrow and nearly symmetric, while the modi of the histograms (Fig. 5/b) are in same interval. The differences appear between the crushed and intact samples that belong to the same rock material. The histograms (Fig.5/a) of the crushed samples are shifted towards the higher HU values and are also more skewed in that direction. The box plots also suggest (Fig. 5/b) that the largest difference is typical for the GGM samples. The diversity of OG samples is nevertheless rather uncertain because of the small sample number.

From the CT scans transformed to 1-bit images, the CFL and the D values of the fracture network were determined for each treated sample (Table I.). The mylonite samples were cut perpendicular to the foliation and are characterised by similar CFL means $\left(\mathrm{OGM}_{\mathrm{pp}}=6.25 \mathrm{GGM}_{\mathrm{pp}}=\right.$ 6.62); these are lower values than those typical for the parallel samples $\left(\mathrm{OGM}_{\mathrm{pl}}=10.2 \mathrm{GGM}_{\mathrm{pl}}=\right.$ 13.8). A similar tendency is shown for the fractal dimension values; the parallel GGM samples are in the higher interval of the D values. The two fracture network geometry parameters, CFL and D seem able to discriminate between the lithologies (Fig. 5.). 


\subsection{Rock mechanical test results}

\subsubsection{Results of non-destructive test}

The results of ultrasonic wave velocity measurements are presented in the Table I.

\subsubsection{Results of destructive tests}

Using the standard unconfirmed compressive tests, the following parameters were determined: uniaxial compressive strength $\left(\sigma_{c}\right)$, elastic modulus (or Young's modulus) $(E)$ and the Poisson's rate value ( $v$ ) (Table I). In Fig. 6, typical measured stress-stain curves are presented, which also show the elastic lines.

Generally the perpendicular samples have higher compressive strength values $\left(\operatorname{mean}_{\mathrm{pl}}=51.1\right.$ $\mathrm{MPa}$, mean $_{\mathrm{pp}}=66.9 \mathrm{MPa}$ ) (Table I.). Concerning the elastic modulus, the GGM lithology can be characterised by a large standard deviation, while its mean is the lowest. The Young's modulus of GGM is slightly lower $\left(\operatorname{mean}_{\mathrm{pl}}=9.1 \mathrm{GPa}, \operatorname{mean}_{\mathrm{pp}}=11.87 \mathrm{GPa}\right)$ than the OGM samples $\left(\operatorname{mean}_{\mathrm{pl}}=\right.$ 13.56 GPa). In the case of GGM the specimens with parallel orientation are situated at the bottom of the range.

According to the commonly used rock engineering classification system, the rock material can be classified using the ratio of the elastic modulus and the compressive strength. Deere and Miller (1966) suggested a classification system presented in Fig. 7. The KIHA-NE samples exhibit a close to linear variation on this plot and they lie at the boundary of the low and average modulus ratio fields. Although the rock types appear mixed on the plot, all parallel GGM samples show significantly lower strength data than the other samples.

The Poisson's ratio values were also measured and calculated. However, the Poisson's ratio could not be measured for some samples (Table I.). While the OGM results range in a well-defined interval (0.03-0.12 MPa), the GGM results vary in a rather wide range $(0.02-0.5 \mathrm{MPa})$. With respect to the orientation, the specimens cannot be separated.

The destruction work shows big differences depending both on the lithology and the sample orientation (Table I.). Plotted with compressive strength data, samples exhibit a monotone, close to linear function (Fig. 8/a). The parallel samples are presented in the lower interval of the parameters, while the GGM and especially the parallel GGM samples show the lowest values.

\subsubsection{Relationships between the rock mechanical and fracture network parameters}

Systematic evaluation of different parameters suggests that several of them are in tight relationship with each other. Fractal dimension of the fracture pattern decreases with increasing destruction work (Fig. 8/b). The separation tendency of the parallel samples, especially the parallel 
GGM samples is evident on this plot. In these specimens, a dense fracture network with high D values evolved by low destruction work. The two geometric parameters of the fracture pattern, D and CFL, increase together (Fig. 8/c). On the other hand with increasing Young's modulus, the CFL values show a slightly decreasing trend (Fig. 8/d); the parallel GGM samples are shifted towards the region of a lower Young's modulus and higher CFL values.

\subsection{Results of statistical methods}

In order to determine those parameters that can be used to distinguish the a priori known petrological groups, discriminant function analyses were carried out.

In the first step of the analysis the two petrologically most different units, the OG with its mylonite (OGM) and GGM were investigated. The coinciding histogram (Fig. 9/a) suggests that the two groups can clearly be separated using the discriminant score $\left(\mathrm{D}_{\mathrm{A}}\right)$ :

$$
\mathrm{D}_{\mathrm{A}}=2.3 \mathrm{~W}_{\mathrm{d}}-2.8\left(\mathrm{E} / \sigma_{\mathrm{c}}\right)-\mathrm{CFL}+0.8 \mathrm{HU}+0.8 \mathrm{E}+0.7 \mathrm{D}
$$

where: $W_{d}$ is the destruction work, $E$ is the Young's modulus, $\sigma_{c}$ is the compressive strength, HU is the mode of the CT scan histogram, CFL is the cumulative fracture length and D is the fractal dimension of the fracture network. In the next step, the separation of OG and OGM on the basis of rock mechanical data was attempted. The results suggest that the two groups cannot be distinguished as they exhibit a unimodal histogram (Fig. 9/b). The discriminant function in this case is:

$$
\mathrm{D}_{\mathrm{B}}=9.7 \mathrm{~W}_{\mathrm{d}}+10.4\left(\mathrm{E} / \sigma_{\mathrm{c}}\right)-12 \sigma_{\mathrm{c}}+1.3 \mathrm{E}-0.8 \mathrm{HU}+0.5 \mathrm{CFL}
$$

Finally, inside the GGM lithology the parallel samples were compared with those that were cut perpendicularly. The resulting plot (Fig. 9/c) shows two distinct groups separated by scores calculated based on the discriminant function of:

$$
\mathrm{D}_{\mathrm{C}}=7.3 \mathrm{D}-8.5 \mathrm{CFL}-7.5 \mathrm{E}+5.6 \mathrm{HU}+5.2 \mathrm{v}_{\mathrm{UH}}+4.3 \sigma_{\mathrm{c}}
$$

where $v_{U H}$ is the ultrasonic wave velocity.

If all three groups (OG and OGM, GGM parallel, GGM perpendicular) are involved in the analysis simultaneously (Fig. 9/d) they can be separated unambiguously using the discriminant functions:

$$
\begin{aligned}
& \text { Function } 1=6.3 \mathrm{~W}_{\mathrm{d}}-7.2 \sigma_{\mathrm{c}}-3.6 \mathrm{CFL}+2.3 \mathrm{E}+1.9 \mathrm{v}_{\mathrm{UH}}+1.4 \mathrm{D}+1.3 \mathrm{HU} \\
& \text { Function } 2=8.1 \mathrm{~W}_{\mathrm{d}}-7.7 \sigma_{\mathrm{c}}+5.4\left(\mathrm{E} / \sigma_{\mathrm{c}}\right)-1.5 \mathrm{D}+1.5 \mathrm{v}_{\mathrm{UH}} .
\end{aligned}
$$

\section{Discussion}




\subsection{The nature of the KIHA-NE reservoir rocks}

According to previous investigations (unpublished reports), the metamorphic basement of the KIHA-NE Field forms a heterogeneous fractured reservoir with oil-water phase boundaries at three different depths inside the rock body. Moreover, numerous neighbouring wells do not communicate with each other hydrodynamically, suggesting a highly compartmentalised fractured reservoir. The reservoir features are extremely heterogeneous throughout the rock body; in a $\mathrm{CH}$ productive interval the porosity is $2-20 \%$, whilst in a barren section it is $0 \%$. Nevertheless, a potential connection between the reservoir properties and lithological characteristics has never been previously studied. In the course of rock classification, we identified four blocks with different lithologies (Fig. 2); the orthogneiss with amphibolite xenoliths and granite intrusions, the orthogneiss mylonite, the graphitic gneiss mylonite and the graphitic carbonate phyllite (Nagy and M. Tóth, IN PRESS). On the basis of macroscopic and microscopic descriptions, the intensity of natural fracturing as well as the presence of oil spots, suggests that the GGM and the OGM units may serve as the main migration pathways and as reservoir rocks. In the case of the GGM samples the cavities and dissolved carbonate nets seem to contribute to the enhancement of the reservoir properties.

Ultrasonic wave velocity (Table I.) and CT scan measurement (Fig. 5) were carried out as non-destructive tests on the intact samples. The results do not show any significant differences between the lithologies; the measured values vary in narrow intervals in the case of each rock type, except for the HU values of the OGM samples; its wide range is probably caused by the mineralogical and microstructural heterogeneities of this lithology. Even slight variations in chemical composition of the protolith may cause remarkable differences in mica content, while different intensities of deformation may result in heterogeneous grain size reduction and various mineral alterations. Interaction of all these factors may have significantly modified rock density and thus the HU values measured by CT.

\subsection{The provoked fracturing of the rock types}

In the course of compression tests, an artificial fracture network was evolved in the rock samples. Cracks can be evolved in the rock body, when the local stress exceeds the local strength (Batzle et al., 1980). According to Gottschalk (1990) the stress concentration in the granitic and the mechanically similar gneissic rocks, has four main sources: (1) presence of micropores, grainscale cavities and heterogeneities, (2) pre-existing microcracks, (3) elastic mismatches between constituent minerals, and (4) slip and frictional sliding on favourably oriented phylosillicate cleavage planes. The role of the preferred orientation of biotite grains in microcrack nucleation within the neighbouring phases is also emphasised (Gottschalk et al., 1990; Seo et al., 2002). Batzle 
et al. (1980) also notes the role of the pre-existing microcrack and grainscale cavity orientation, which decides opening or closing as a function of the stress field.

The fracture network evolved in the course of the compression treatment could be visualised in 3D by CT scans. In evaluating the vertical and horizontal sections, remarkable differences concerning both lithology and orientation become conspicuous (Fig. 4). Whilst in the samples perpendicular to the foliation just a few fractures evolved, whereas in the parallel samples numerous fractures were created. Mylonites, especially the GGM samples exhibit an even more dense fracture network than any other set of specimens. In addition to visualisation, numerical data derived from CT sections (cumulative fracture length - CFL, and the fractal dimension value - D of the created fracture network) further confirm these differences (Table I.); the parallel GGM samples are characterised by the highest CFL and D values. Further numerical data, the compressive strength, the Young's modulus, the Poisson ratio and the destruction work were provided by the compression tests (Table I.). Although the number of the specimens was not sufficient to obtain statistically reliable data, the results do show the most important rock mechanical behaviour of the rock materials.

There are several rock mechanical classification schemes and interpretations used by rock engineers to describe the behaviour of rock masses (e.g., Q-system by Barton et al., 1974; NAMT by Rabcewicz, 1964; Rock Mass Rating (RMR) system by Bieniawski, 1989). These methods are mostly based on empirical observations and are developed for special rock mechanical problems. Although they define relative rather than absolute metrics, these schemes may be suitable for comparing the mechanical behaviour of diverse rock types within a given field. According to Deer and Miller's (1966) diagram $\left(\sigma_{c}-E\right)$, most studied samples plot into the sedimentary rather than the expected metamorphic rocks field, even if they are close to the boundary of the two fields (Fig. 7). This suggests that the samples behave as sedimentary rocks in a mechanical sense; they do not show the features of classical metamorphic rocks. Although, their strength does not change significantly, the investigated samples have lower elasticity modulus than expected in the case of normal metamorphic rocks.

The different mechanical and fracture network parameters show characteristic relationships and co-variation trends (Fig. 8). The CFL correlates with the D values; they increase together suggesting a more complicated fracture network consists of longer fractures. Fractal dimension is also in tight relationship with destruction work, such that the fracture system is more prone to better communicate when it was evolved by lower destruction work. It also suggests that the rock material with high $\mathrm{D}$ values is more brittle and easier to crush. According to the plots on Fig. 8/b-c, CFL could be useful in differentiating the samples by orientation, whilst the D value could be used for lithology differentiation. The plot of $\mathrm{W}_{\mathrm{d}}-\sigma_{\mathrm{c}}$ (Fig. 8/a) may discriminate both concerning orientation 
and lithology. On each plot the OGM samples usually plot with intermediate values close to the few data points of OG. In the case of GGM lithology however, the data points of the parallel samples usually separate from the others; in addition, in several cases they separate from the perpendicular GGM data too. The remarkable influence of sample orientation on fracturing tendency suggests the highly anisotropic behaviour of the GGM lithology. In general, on the basis of all these plots, the parallel GGM samples need the lowest destruction work to create high CFL and D data that is a complex system. Consequently, this rock type has the best chance to form a communicating fracture network. Furthermore, orientation of the recent stress field may have an important role on the closing or opening tendency of the natural fractures of the GGM block inside the reservoir, because of the highly anisotropic behaviour of this lithology.

Analysis of the CT images also makes the study of changes in the uncrushed rock matrix possible. This kind of evaluation can be carried out by omitting the fractures of the analysis. The results of intact and crushed samples were compared (Fig. 5) in the case of the mylonitised rock units (OGM, GGM). Data obtained for the crushed OGM samples vary in a rather wide range, nearly overlapping with the original interval measured for the intact samples (Fig. 5/b). As the HU values correlate with the rock density, the results suggest that in the case of the OGM, there was a slight density increase during the compressive test inside the rock matrix. Both the macroscopic and microscopic description, as well as the CT interpretation of this rock type, implies that the original OGM samples do not include a visible amount of microcracks or microcavities, which could become closed during the compressive test. Although, microcracks usually nucleate in mica neighbouring mineral phases, causing a density decrease and the OGM samples contain abundant amounts of phylosillicates (biotite, chlorite and sericite), the effect of this behaviour is not detectable on the CT scans. Even if this phenomenon may be important, the size and the amount of these microcracks in the samples are probably too low to appear in the HU values.

During deformation, as a result of the migrating fluids, fine grained muscovite + quartz assemblages form replacing relatively strong feldspars. Due to this process, the reaction (also called secondary) softening (e.g., White and Knippe, 1978; Williams and Dixon, 1982; Wibberly, 1999) generates a softer, looser zone in the rock body. The muscovitisation reactions can facilitate the deformation (Wiberly, 1999) and these reactions indicate fluid mobility in the shear zones during the deformation process (Williams and Dixon, 1982). These softer zones afterwards undergo further loosening in the course of the uplift of the rock unit. Rock mechanical compression tests could generate compaction in these looser zones that may cause a density increase in the HU values of the specimens.

On the other hand, in the case of GGM, the HU parameters of the intact and crushed samples exhibit a characteristic difference. The difference between the HU modi (Fig. 5/b) as well as the 
histograms of the crushed and intact GGM samples (Fig. 5/a) clearly indicate a density increase during the mechanical treatment. This behaviour implies some essential rock characteristics may have an influence on the rock fracturing process. The GGM samples in their natural appearance contain abundant cracks, cavities and dissolved carbonate nests, which are probably accompanied by smaller microcracks and microcavities invisible to the naked eye. This microscopic and/or submicroscopic pore space could behave as significant matrix porosity that assigns a sedimentary feature for the rock, in accordance with the suggestion of the Deer and Miller (1966) plot.

Although, prior to sample preparation, naturally unfractured intact specimens were selected, the presence of a few microcracks, microcavies and dissolved nests cannot be discounted. During the compressive test these tiny unconformities may have closed and caused the density increase. As this phenomenon takes place on the microscopic scale and the CT scan has a $1 \mathrm{~mm}$ resolution, only the HU value distribution could serve information about the density change. Moreover, compaction of the loosened mica rich zones also plays a notable part in the density increase during the compression test.

In summary, we can state that the petrologically different rock types have remarkably different brittle behaviours. The low fracture network parameters (CFL, D) and the few provoked fractures detected on the CT images, confirm the former suggestion that the OG block does not behave as a good fractured reservoir. The OGM lithology is characterised by moderate anisotropy and fracture tendency; the fractal dimension and CFL values do not suggest formation of a complicated and connected fracture system. High anisotropy and the large, possibly communicating fracture system that characterises the GGM, is achieved by much lower work investment than for any other rock type. In fact, this mylonite variety behaves as a sedimentary rock based on its rock mechanical parameters. On the other hand, although this lithology is the best candidate to contain large fractured zones in the whole reservoir, at reservoir pressure conditions microcracks and microcavities may become closed, significantly decreasing the original matrix porosity. Otherwise, overpressure in the reservoir may keep the cracks open as well resulting just in the opposite effect.

\subsection{Discrimination of the lithology groups}

Detailed data evaluation clearly infers that the four rock types are different not only concerning their petrological characteristics, but also in their rock mechanical behaviour, especially in the ability to form mutual fracture systems. To quantify how well the lithology groups can be distinguished based on the measured numerical parameters, discriminant function analysis was applied. Furthermore, this approach also can identify those rock mechanical parameters that are responsible for characterising each group. In the first step, one can see that the OG and the OGM samples can be separated from the GGM specimens (Fig. 9/a) using the discriminant function $\mathrm{D}_{\mathrm{A}}$ 
(Eq. 3) that is based mainly on destruction work and elasticity/compressive strength. The plots of the rock mechanical parameters also showed that the lithotypes can be separated using the $W_{d}-\sigma_{c}$ (Fig. 8/a) and the $E-\sigma_{c}$ (Fig. 7) pairs of variables. Observing these plots, the OG with OGM group with higher strength and a slightly higher elasticity modulus, clearly needs more invested work to crush compared to the GGM samples. Furthermore, CFL, the third most important parameter of the $\mathrm{D}_{\mathrm{A}}$ discriminant function (Eq. 3), is in a reverse relationship with the destruction work, suggesting that samples crushed using less work tend to generate more a complex fracture network. As the GGM needs less destruction work to be broken, coinciding with higher CFL values, the GGM lithology exhibits the better reservoir features.

Using discriminant analysis, no straightforward separation between the OG and OGM samples is possible (Fig. 9/b). It is caused by gradual transition between the two rock types in all rock mechanical features (Fig. 7.), suggesting a continuous increase in the measure of shearing towards the highly deformed samples (mylonites).

Thirdly, inside the GGM unit a remarkable difference can be computed between the parallel and the perpendicular samples. The bimodal feature of this lithology is slightly observable on Fig 9/a, whilst in Fig. 9/c the separation of the differently orientated samples becomes obvious. In the $\mathrm{D}_{\mathrm{C}}$ discriminant function (Eq. 5) that is responsible for separating samples of different orientations, the main factors are CFL and D that are the main geometric parameters of the fracture network. Absence of the rock mechanical variables indicates that there is no difference in the material itself, rather the behaviour of the GGM lithology is characterised by high anisotropy due to mylonitic foliation.

Discriminant function analysis of all three petrologically different groups of rocks shows coincident results. In Fig. 9/d three sample groups are separated; the OG and OGM form one cluster, while the parallel and perpendicular GGM samples create two additional groups. In the discriminant functions F1 and F2 (Eq. 6,7) the primary differentiating factors are destruction work and compressive strength, while the secondly factors are cumulative fracture length and the fractal dimension value. The other rock mechanical and petrophysical parameters, like HU values, or the ultrasonic wave velocity have subordinate roles in the group formation.

\section{Conclusions}

The Kiskunhalas-NE fractured metamorphic reservoir is characterised by the presence of rock types with different metamorphic and structural evolutions. On the basis of complex investigation we can state that the petrologically different rock types have remarkably different rock mechanical behaviours. We suggest that graphitic gneiss mylonite zone may offer the best reservoir 
characteristics. The results also show that all mechanical parameters are highly anisotropic and are determined by previous structures of the rock types. Therefore, beyond the lithology, the relationships between the recent stress field and the orientation of the preserved foliation of the metamorphic rocks have an important role in the reservoir features.

\section{Acknowledgement}

We thank MOL Hungarian Oil and Gas Company for making the study of the samples and thin sections possible. Balázs Kiss is thanked for the fruitful discussions about the behaviour of the KIHA-NE reservoir. The publication is supported by the European Union and co-funded by the European Social Fund. Project title: "Broadening the knowledge base and supporting the long term professional sustainability of the Research University Centre of Excellence at the University of Szeged by ensuring the rising generation of excellent scientists”. Project number: TÁMOP-4.2.2/B10/1-2010-0012. English was corrected by Proof-Reading-Service.com.

\section{References}

Antonellini M, Aydin A, Pollard D D, D’Onfro P 1994: Petrophysical study of faults in sandstone using petrographic image analysis and X-ray computerized tomography. Pure Appl. Geophys., 143, 181-201.

Aoya M, Kouketsu Y, Endo S, Shimizu H, Mizukami T, Nakamura D, Wallis S 2010: Extending the applicability of the Raman carbonaceous-material geothermometer using data from contact metamorphic rocks. J. of Met. Geol., 28/9, 895-914.

Árkai P 1978: A Kiskunhalas ÉK-I terület mezozoikumnál idősebb metamorf és magmas képződményeinek szénhidrogénprognózist elősegítő ásványtan-kőzettani és geokémiai vizságlata. MTA GKI (Manuscript).

Árkai P 1991: Kishőmérsékletű regionális metamorfózis. DSc Thesis. Budapest.

ASTM 2004: Annual Book of ASTM Standards, 4/ 08, Soil and Rock. American Society for Testing and Materials, Philadelphia, PA.

Barton N R, Lien R, Lunde J 1974: Engineering classification of rock masses for the design of tunnel support. Rock Mech. and Rock Eng. 4, 189-236.

Barton C C, Larsen E 1985: Fractal geometry of two-dimensional fracture networks at Yucca Mountain, Southwestern Nevada. In: Stephanson O (ed.): Proc. Int. Symp. on Fundamentals of Rock Joints, 77-84.

Barton C C 1995: Fractal analysis of scaling and spatial clustering of fractures. In: Barton C C, La Pointe P R (eds.): Fractals in the Earth Sciences. Plenum Press, New York, 168.

Be'suelle P, Baud P, Wong T-F 2003: Failure mode and spatial distribution of damage in Rothbach Sandstone in the brittle-ductile transition. Pure appl. geophys., 160, 851-868

Batzle M L, Simmons G, Siegfried R W 1980: Microcrack closure in rocks under stress: direct observation. J. of Geophy. Res., 85/B12, 7072-7090.

Beyssac O, Goffé B, Chopin C, Rouzaud N 2002: Raman spectra of carbonaceous material in metasediments: a new geothermometer. J. Met. Geol., 20, 859-871.

Bieniawski ZT 1967: Mechanism of brittle fracture of rock, parts I, II and III. Int. J. Rock Mech. Min. Sc.i Geomech. Abstr. 4/4, 395-430.

Bieniawski Z T 1989: Engineering rock mass classifications: a complete manual for engineers and geologists in mining, civil, and petroleum engineering. Wiley-Interscience. 40-47 
Bryon DN, Atherton M P, Hunter R H 1995: The interpretation of granitic textures from serial thin sectioning, image analysis and three-dimensional reconstruction. Mineral. Mag., 59, 203-11.

Cai M, Kaiser P K, Tasaka Y, Maejima T, Morioka H, Minami M 2004: Generalized crack initiation and crack damage stress thresholds of brittle rock masses near underground excavations. Int. J. Rock Mech. Min. Sci., 41/5, 833-847

Cai M 2010: Practical estimates of tensile strength and Hoek-Brown strength parameter $m_{i}$ of brittle Rocks. Rock Mech. Rock Eng. 43/2, 167-184.

Carlson W D, Denison C, Ketcham R A 2000: High-resolution X-ray computed tomography as a tool for visualization and quantitative analysis of igneous textures in three dimensions. Visual Geosciences, 4/3, 1-14.

Cooper M R, Hunter R H 1995: Precision serial lapping, imaging and three-dimensional reconstruction of minus-cement and post-cementation intergranular pore-systems in the Penrith Sandstone of north-western England. Mineral. Mag., 59, 213-20.

Cserepes L 1980: A Duna-Tisza Közi karbonnál idősebb képződmények petrológiai vizsgálata MSZKFI, Budapest.

Cserepes-Meszéna B 1986: Petrography of the crystalline basement of the Danube-Tisza Interfluve (Hungary). Acta Geol. Hung., 29/3-4, 321-339.

Csontos L, Nagymarosy A, Horváth F, Kovac M 1992: Tertiary evolution of the Intra-Carpathian area: a model. Tectonophysics, 208, 221-241.

Csontos L, Nagymarosy A 1998: The Mid-Hungarian line: a zone of repeated tectonic inversions. Tectonophysics, 297/1-4, 51-71.

Deere D U, Miller R P 1966: Engineering classification and index properties of intact rock. Tech. Report No. AFWL-TR-65-116, Air Force.

Denison C, Carlson W D, Ketcham R A 1997. Three-dimensional quantitative textural analysis of metamorphic rocks using high-resolution computed X-ray tomography: Part I. Methods and techniques. J. of Met. Geol., 15/1, 29-44.

Denison C, Carlson W D, 1997: Three-dimensional quantitative textural analysis of metamorphic rocks using high-resolution computed X-ray tomography: Part II. Application to natural samples. $J$. of Met. Geol., 15/1, 45-57.

D. Lörincz K 1996: Feszültségtér történet meghatározása szeizmikus szelvényeken azonosított többfázisú tektonizmus alapján, a Szolnoki flis öv nyugati peremén. Magyar Geofizika, 37/4, 228246.

Földes T, Árgyelán G B, Kiss B, Hips K, Bogner P, Repa I 2004: Application of medical Computer Tomograph measurement to 3D reservoir characterization. Acta Geol. Hung., 47/1, 63-73.

Gercek H 2007: Poisson's ratio values of rocks, Int. J. Rock Mech. Mining Sci., 44, 1-13.

Gottschalk R R 1990: Mechanical anisotropy of gneiss: Failure criterion and textural sources of directional behavior. J. of Geophysical Research, 95/B13, 21,613-21,634.

Haas J, Péró Cs 2004: Mesozoic evolution of the Tisza Mega-unit. Int.J. of Earth Sci., 93/2, 297 313.

Hirata T 1989: Fractal dimension of fault system in Japan: fracture structure in rock fracture geometry at various scales. Pure and Applied Geophysics, 131, 157-170.

Horváth F, 1995: Phases of compression during the evolution of the Pannonian Basin and its bearing on hydrocarbon exploration. Mar. Petrol. Geol., 12/8, 837-844.

Horváth F, Bada G, Szafián P, Tari G, Ádám A, Cloetingh S 2006. Formation and deformation of the Pannonian basin: constraints from observational data. In: Gee D G, Stephenson R A (Eds.): European Lithosphere Dynamics, Geological Society, London, Memoirs, 32, 191-206.

Huddlestone-Holmes C R, Ketcham R A 2010: An X-ray computed tomography study of inclusion trail orientations in multiple porphyroblasts from a single sample. Tectonophysics, 480, 305-320.

Hounsfield G N 1973: Computerized traverse axial scanning (tomography). Br. J. Radiol., 46, 10161022.

Ikeda S, Nakano T, Nakashima Y 2000: Three-dimensional study on the interconnection and shape of crystals in a graphic granite by X-ray CT and image analysis. Mineral. Mag., 64/5, 945-959. 
ISRM 2006: The complete ISRM suggested methods for rock characterization, testing and monitoring. Eds: Ulusay R; Hudson J A) ISRM, 628.

Jaeger J C, Cook N G W, Zimmermann R W 2007: Fundamentals of Rock Mechanics (Fourth Edition). Blackwell Publishing, 475.

Kawakata H, Cho A, Kiyama T, Yanagidani T, Kusunose K, Shimada M 1999: Three-dimensional observations of faulting process in Westerly Granite under uniaxial and triaxial conditions by X-ray CT scan. Tectonophysics, 313, 293-305.

Ketcham R A, Carlson W D 2001: Acquisition, optimization and interpretation of X-ray computed tomographic imagery: applications to the geosciences. Comp. \& Geosci., 27, 381-400.

Ketcham R A 2005: Three-dimensional grain fabric measurements using high-resolution X-ray computed tomography. J. of Struct. Geol., 27, 1217-1228.

Kruhl J H, Nega M 1996: The fractal shape of sutured quartz grain boundaries: application as a geothermometer. Geol. Rundsch, 85, 38-43.

Lelkes-Felvári Gy, Frank W, Schuster R 2003: Geochronological constraints of the Variscan, Permian-Triassic and eo-Alpine (Cretaceous) evolution of the Great Hungarian Plain basement. Geol. Carpathica, 54/5, 299-315.

Lelkes-Felvári Gy, Frank W 2006: Geochronology of the metamorphic basement, Transdanubian part of the Tisza Mega-Unit. Acta Geol. Hung. 49/3, 189-206.

Li J, Du Q, Sun C 2009: An improved box-counting method for image fractal dimension estimation. Pattern Recognition, 42/11, 2460-2469.

Liu Q, Brosch F J, Riedmüller G 2004: The significance and prediction of different rock mass characteristics for rock engineering. Int. J. of Rock Mech. and Mining Sci., 41/1, 103-117.

Matsumoto N, Yomogida K, Honda S 1992: Fractal analysis of fault systems in Japan and the Philippines. Geophysical Research Letters, 19/4, 357-360.

Marschallinger R 1998: Correction of geometric errors associated with the 3-D reconstruction of geological materials by precision serial lapping. Mineral. Mag., 62, 783-92.

Martin C D 1993: The strength of massive Lac du Bonnet granite around underground opening. Ph.D. thesis, p 278

Mees F, Swennen R, Van Geet M, Jacobs P 2003: Applications of X-ray computed tomography in the geosciences. Geological Society, London, Special Publications, 215, 1-6.

M. Tóth T, Schubert F, Földes T, Hollós Cs, Komlósi J 2002: Modelling of the fractured Dorozsma crystalline reservoir, SE Pannonian Basin. EAGE Annual Meeting Abstracts, 297.

M. Tóth T, Szücs É, Schubert F, Hollós Cs 2004: Conceptual fracture network model of the crystalline basement of the Szeghalom Dome (Pannonian Basin, SE Hungary). Acta Geol. Hung., 47/1, 19-34.

M. Tóth T, Zachar J 2006: Petrology and deformation history of the metamorphic basement in the Mezősas-Furta crystalline high (SE Hungary). Acta Geol. Hung., 49/2, 165-188.

M Tóth T, Redlerné Tátrai M, Kummer I 2009: A Szeghalom környéki metamorf aljzat kiemelkedés szerkezetfejlődése és felépítése kőzettani és szezmikus adatok alapján. Magyar Geofizika, 49/4, 143-151.

Nagy Á, M. Tóth T, 2012: Petrology and tectonic evolution of the Kiskunhalas-NE fractured CHreservoir, S-Hungary. Central European Geology 55/1, 1-22.

Ortega O J, Marrett R A, Laubach S E 2006: A scale-independent approach to fracture intensity and average spacing measurement. AAPG Bulletin, 90/2,193 - 208

Philpotts A R, Shi J, Brustman C 1998: Role of plagioclase crystal chains in the differentiation of partly crystallized basaltic magma. Nature, 395, 343-346.

Rabcewicz L 1964: The New Austrian Tunnelling Method, Part one. Water Power, Novemner 1964, 453-457, Part two, Water Power, December 1964, 511-515.

Rahl J, Anderson K, Brandon M, Fassoulas C 2005: Raman spectroscopic carbonaceous material thermometry of low-grade metamorphic rocks: Calibration and application to tectonic exhumation in Crete, Greece. Earth and Planetary Sci. Letters, 240/2, 339-354.

Raynaud S, Fabre D, Mazetolle F, Geraud Y, Latiere H J 1989: Analysis of the Internal Structure of 
Rocks and Characterization of Mechanical Deformation by a Non-destructive Method: X-ray Tomodensitometry. Tectonophysics, 159, 149-159.

Schubert F, Diamond L W, M. Tóth T 2007: Fluid inclusion evidence of petroleum migration through a buried metamorphic dome in the Pannonian Basin, Hungary. Chemical Geology, 244/3-4, 357-381.

Seo Y S, Jeong G C, Kim J S, Ichikawa Y 2002: Microscopic observation and contact stress analysis of granite under compression. Engineering Geology, 63/3-4, 259-275.

Szederkényi T 1984: Az Alföld kristályos aljzata és földtani kapcsolatai. DSc Thesis.

Stegena L, Horváth F, Landy I, Nagy Z, Rumpler J 1992: High enthalpy geothermal reservoirs in Hungary. Földtani Közlöny, 122/2-4, 195-208.

Tari G, Horváth F, Rumpler J 1992: Styles of extension in the Pannonian Basin. Tectonophysics, 208, 203-219.

Tari G, Dövényi P, Dunkl I, Horváth F, Lenkey L, Stefanescu M, Szafián P, Tóth T 1999: Lithospheric structure of the Pannonian basin derived from seismic, gravity and geothermal data. In: Durand B, Jolivet L, Horváth F, Séranne M (eds.): The Mediterranean Basins: Tertiary Extension within the Alpine Orogen. Geological Society, London, Special Publications, 156, 215-250.

T. Kovács G 1973: A Duna-Tisza köze déli részének földtani fejlődés története. Dsc Thesis, Szeged, Hungary.

T. Kovács G, Kurucz B 1984: A Dél-Alföld mezozoikumnál idősebb képződményei. MÁFI, Budapest.

Tsuchiya N, Nakatsuka K 1995: A two-dimensional mono-fractal approach to natural fracture networks in rock. Geotherm. Sci. Tech., 6, 63-82.

Van Geet M, Swennen R, Wevers M 2000: Quantitative analysis of reservoir rocks by microfocus X-ray computerised tomography. Sedimentary Geology, 132, 25-36.

Vinegar H J, De Waal J A, Wellington S L 1991: CT Studies of Brittle Failure in Castlegat Sandstone. Int. J. Rock Mech. Min. Sci., 28, 441-448.

Wellington S L, Vinegar H J 1987: X-Ray Computerized Tomography. J. Pet. Tech., 39, 885-898.

Wibberley C 1999: Are feldspar-to-mica reactions necessarily reaction-softening processes in fault zones? J. of Struct. Geol., 21/8-9, 1219-1227.

White S H, Knipe R J 1978: Transformation- and reaction-enhanced ductility in rocks. Journal of the Geological Society, 135/5, 513-516.

Williams G, Dixon J 1982: Reaction and Geometrical Softening in Granitoid Mylonites. Textures and Microstructures, 4/4, 223-239.

Zachar J, M. Tóth T 2004: Pertology of the metamorphic basement of the Tisza Block at the Jánoshalma High, S Hungary. Acta Geol. Hung., 47/4, 349-371.

Zachar J, M. Tóth T, Janák M 2007: Kyanite eclogite xenolith from the orthogneiss terrane of the Tisza Megaunit, Jánoshalma area, crystalline basement of southern Hungary. Lithos, 99/3-4, 249265. 


\section{Legends}

\begin{tabular}{|c|c|c|c|c|c|c|c|c|c|c|c|}
\hline \multirow{2}{*}{$\begin{array}{c}\text { Samp. } \\
N r .\end{array}$} & \multirow[t]{2}{*}{ Lit. } & \multirow[t]{2}{*}{ Or. } & \multirow[t]{2}{*}{$C F L$} & $D$ & $v_{U H}$ & $m . \sigma_{c}$ & c. $\sigma_{c}$ & $E$ & $v$ & \multirow[t]{2}{*}{$E / \sigma_{c}$} & \multirow[t]{2}{*}{$W d$} \\
\hline & & & & \multicolumn{4}{|c|}{$(\mathrm{km} / \mathrm{s})(M p a)(M p a)$} & \multicolumn{2}{|l|}{$(G P a)$} & & \\
\hline III/1 & OG & PL & 11 & 1,46 & 44,90 & 42,4 & 56,8 & 9,58 & - & 169 & 0,337 \\
\hline $\mathrm{VII} / 1$ & OG & PP & 9 & 1,40 & 51,65 & 60,1 & 80,3 & 22,55 & 0,07 & 281 & 0,286 \\
\hline $\mathrm{VIII} / 1$ & OG & PP & 5 & 1,07 & 38,41 & 59,7 & 85,0 & 17,83 & 0,10 & 210 & 0,405 \\
\hline $\mathrm{VIII} / 2$ & OG & PP & 13 & 1,40 & 41,28 & 34,9 & 49,5 & 64 & 0,34 & 175 & 0,284 \\
\hline IV/1 & OGM & PL & 14 & 1,42 & 50,74 & 44,0 & 58,9 & 11,04 & 0,33 & 187 & 0,314 \\
\hline $\mathrm{IV} / 2$ & OGM & PL & 14 & 1,56 & 45,07 & 39,8 & 2,7 &, 04 & - & 247 & 0,213 \\
\hline III/1 & OGM & PL & 9 & 1,50 & 44,48 & 41,9 & 55,8 & 12,00 & 0,12 & 215 & 0,259 \\
\hline $\mathrm{III} / 2$ & OGM & PL & 6 & 1,28 & 43,89 & 44,2 & 60,2 & 5,00 & 0,10 & 249 & 0,242 \\
\hline III/3 & OGM & PL & 8 & 1,24 & 42,11 & 65,3 & 88,2 & 16,70 & 0,03 & 189 & 0,466 \\
\hline IV/3 & OGM & PP & 7 & 1,35 & 40,90 & 41,6 & 55,7 &, 56 & - & 154 & 0,362 \\
\hline IX/1 & OGM & PP & 6 & 1,31 & 50,08 & 71,5 & 100,0 & 34,50 & 0,12 & 345 & 0,290 \\
\hline $\mathrm{VI} / 1$ & GGM & PL & 13 & 1,53 & 46,60 & 37,0 & 49,1 & 15,40 & 0,00 & 314 & 0,157 \\
\hline $\mathrm{VI} / 3$ & GGM & PL & 21 & 1,67 & 44,87 & 20,3 & 26,9 & 6,14 & - & 228 & 0,118 \\
\hline V/1 & GGM & PL & 11 & 1,35 & 43,81 & 24,0 & 32,2 & 64 & 0,00 & 237 & 0,136 \\
\hline $\mathrm{V} / 2$ & GGM & PL & 11 & 1,35 & 47,46 & 34,3 & 45,5 & 8,28 & 0,30 & 182 & 0,250 \\
\hline $\mathrm{V} / 3$ & GGM & PL & 13 & 1,57 & 44,80 & 31,8 & 41,9 & 8,24 & 0,00 & 197 & 0,213 \\
\hline $\mathrm{X} / 1$ & GGM & PP & 7 & 1,39 & 60,23 & 17,8 & 24,2 & 12,60 & - & 521 & 0,046 \\
\hline $\mathrm{X} / 2$ & GGM & PP & 7 & 1,41 & 36,93 & 71,8 & 97,2 & 13,30 & 0,02 & 137 & 0,710 \\
\hline $\mathrm{X} / 3$ & GGM & PP & 6 & 1,32 & 53,95 & 53,3 & 71,1 & 14,52 & 0,10 & 204 & 0,348 \\
\hline $\mathrm{X} / 4$ & GGM & PP & 6 & 1,50 & 42,67 & 32,1 & 41,5 & 10,30 & 0,28 & 248 & 0,167 \\
\hline $\mathrm{X} / 5$ & GGM & PP & 9 & 1,44 & 48,50 & 59,9 & 78,0 & 11,30 & 0,50 & 145 & 0,538 \\
\hline $\mathrm{VI} / 2$ & GGM & $\mathrm{PP}$ & 5 & 1,06 & 30,15 & 52,4 & 67,8 & 9,20 & 0,22 & 136 & 0,500 \\
\hline
\end{tabular}

Table I. Measured data of the samples. Legend: Samp. Nr. - sample number, Lit. - Lithology (OG - orthogneiss, OGM - orthogneiss mylonite, GGM - graphitic gneiss mylonite), Or. - orientation ( $\mathrm{PL}$ - parallel, $\mathrm{PP}$ - perpendicular), CFL - cumulative fracture length, D - fractal dimension value, $v_{U H}-$ ultrasonic wave velocity, m. $\sigma_{c}$ - measured compressive strength, c. $\sigma_{c}$ - corrected compressive strength, $E$ - Young's modulus, $v$ - Poisson's ration, $W d$ - destruction work. 


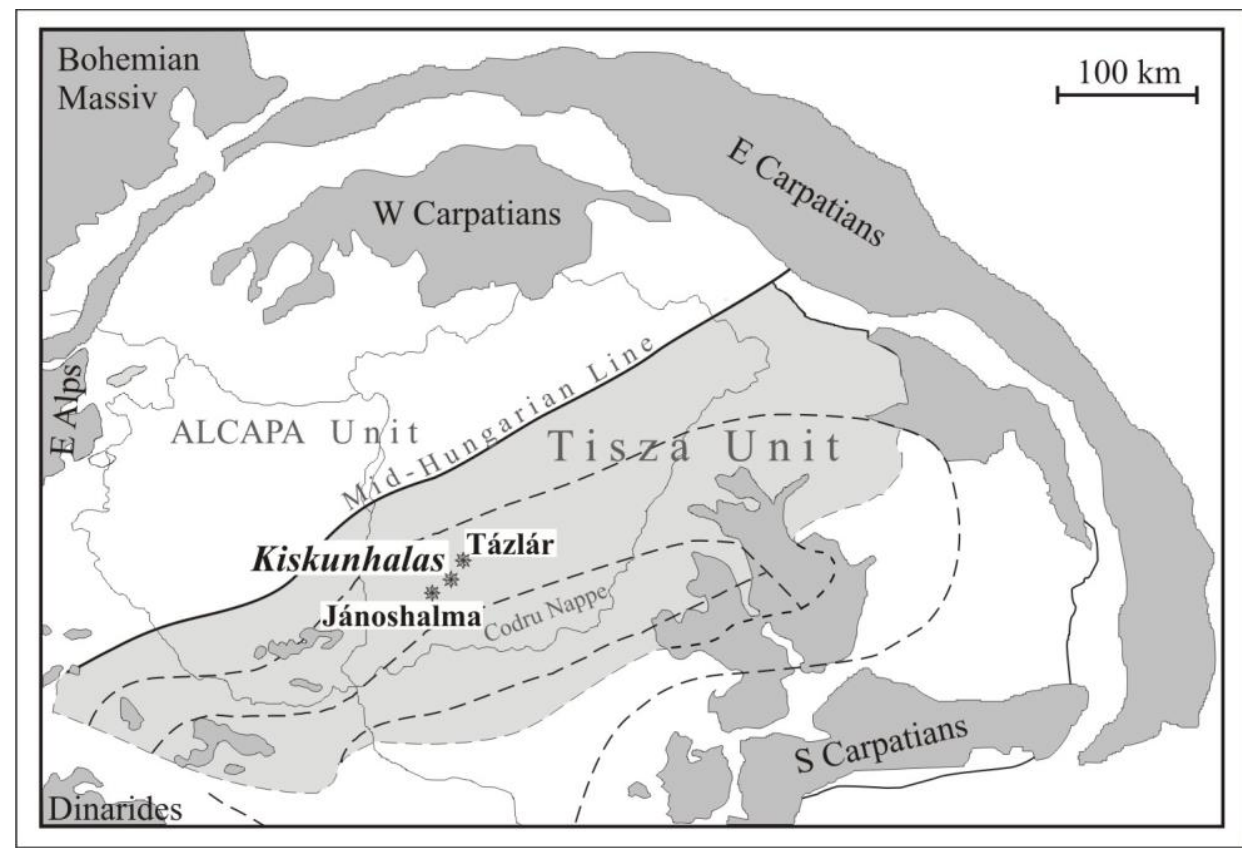

Figure 1. Simplified geological map of the Pannonian Basin in the Alpine-Carpathian-Dinaric system showing the position of the Kiskunhalas and the neighbouring fields. The dashed lines referred to the subunits of Tisza Unit.

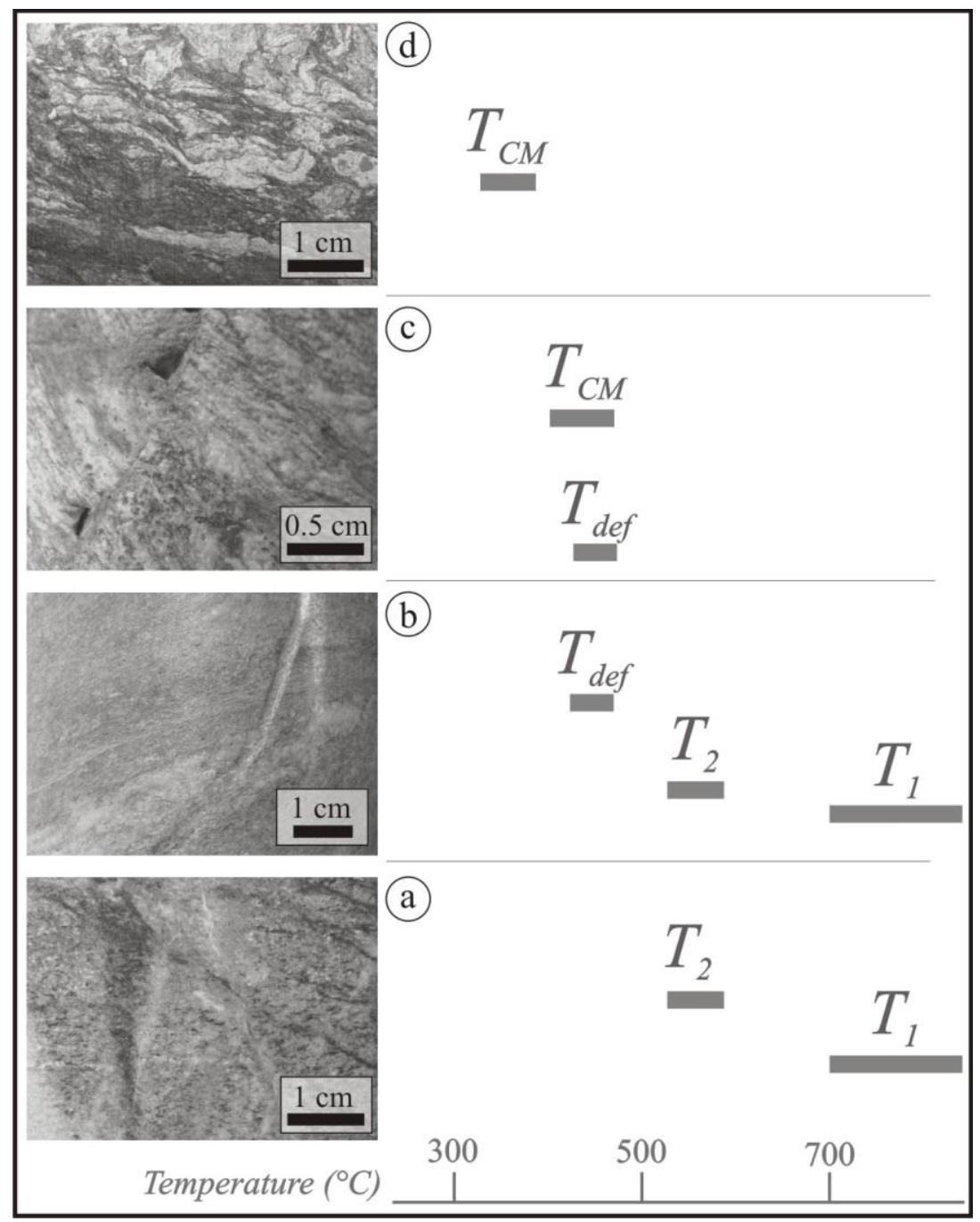

Figure 2. The idealised rock column of KIHA-NE Field (after Nagy and M. Tóth, 2012). Representative macroscopic pictures of the lithologies and its characteristic temperatures: a) 
orthogneiss b) orthogneiss mylonite c) graphitic gneiss mylonite d) graphitic carbonate phyllite $\mathrm{T}_{\mathrm{CM}}$ - temperature of carbonaceous material thermometer by Raman microspectroscopy; $T_{\text {def }}$ temperature of deformation by quartz suture thermometer; T1 and T2 - characteristic temperatures (Zachar and M. Tóth 2004).

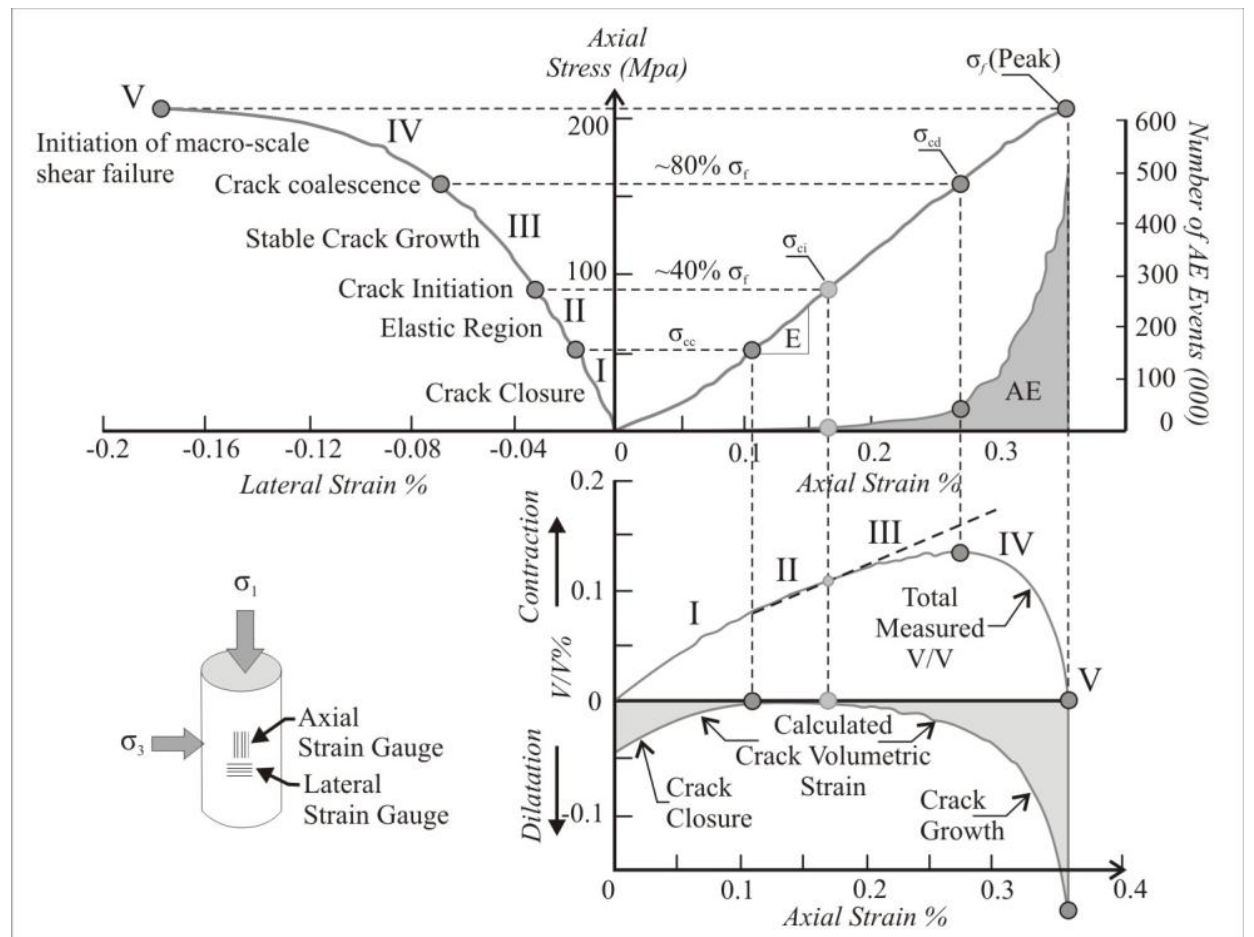

Figure 3. Stress-strain diagram of a rock showing the stages of crack development (after Martin 1993). For the further explanation see the text. 


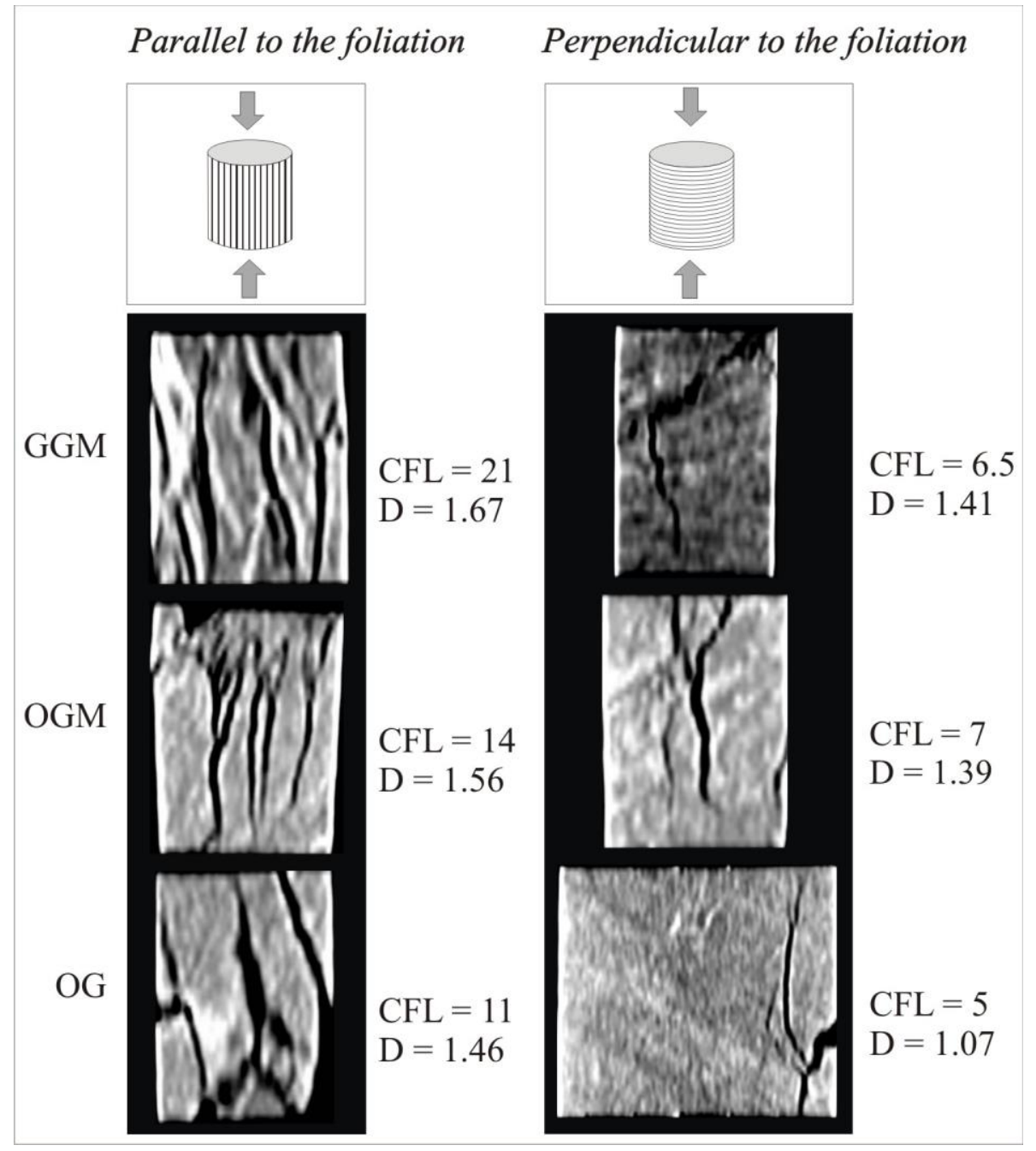

Figure 4. - Characteristic CT scan section of the treated samples considering the sample orientation. The indicated CFL and D values are valid for the presented sample. The evolved fracture network is shown by black colour inside the samples. Legend: OG - orthogneiss, OGM - orthogneiss mylonite, GGM - graphitic gneiss mylonite; CFL - cumulative fracture length, D - fractal dimension value. 

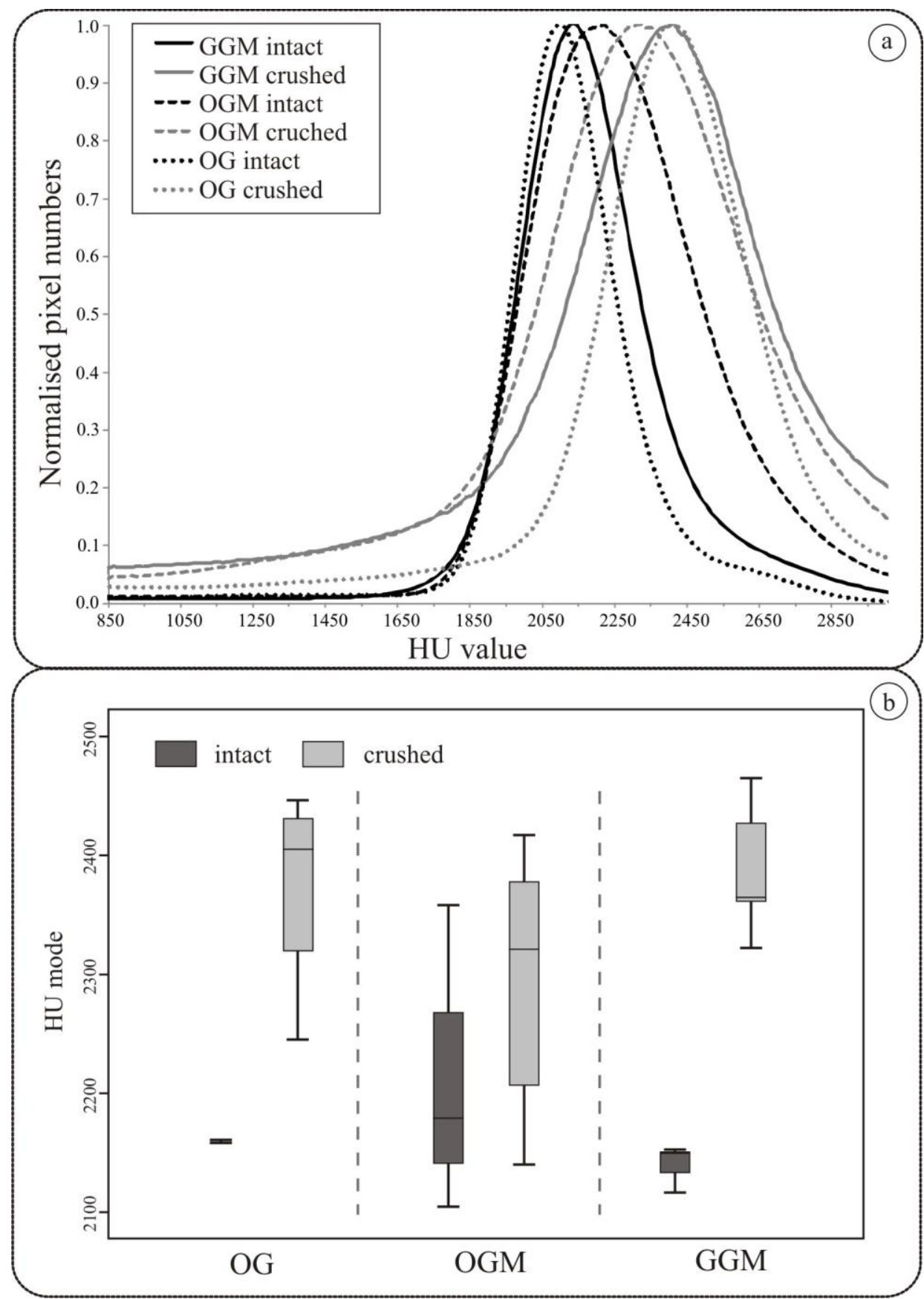

Figure 5. a) Characteristic histogram of the intact and crushed samples; b) boxplot of the mode values of the HU. Legend: OG - orthogneiss, OGM - orthogneiss mylonite, GGM - graphitic gneiss mylonite; $\mathrm{PL}$ - parallel with the foliation sample, $\mathrm{PP}$ - perpendicular to the foliation sample 


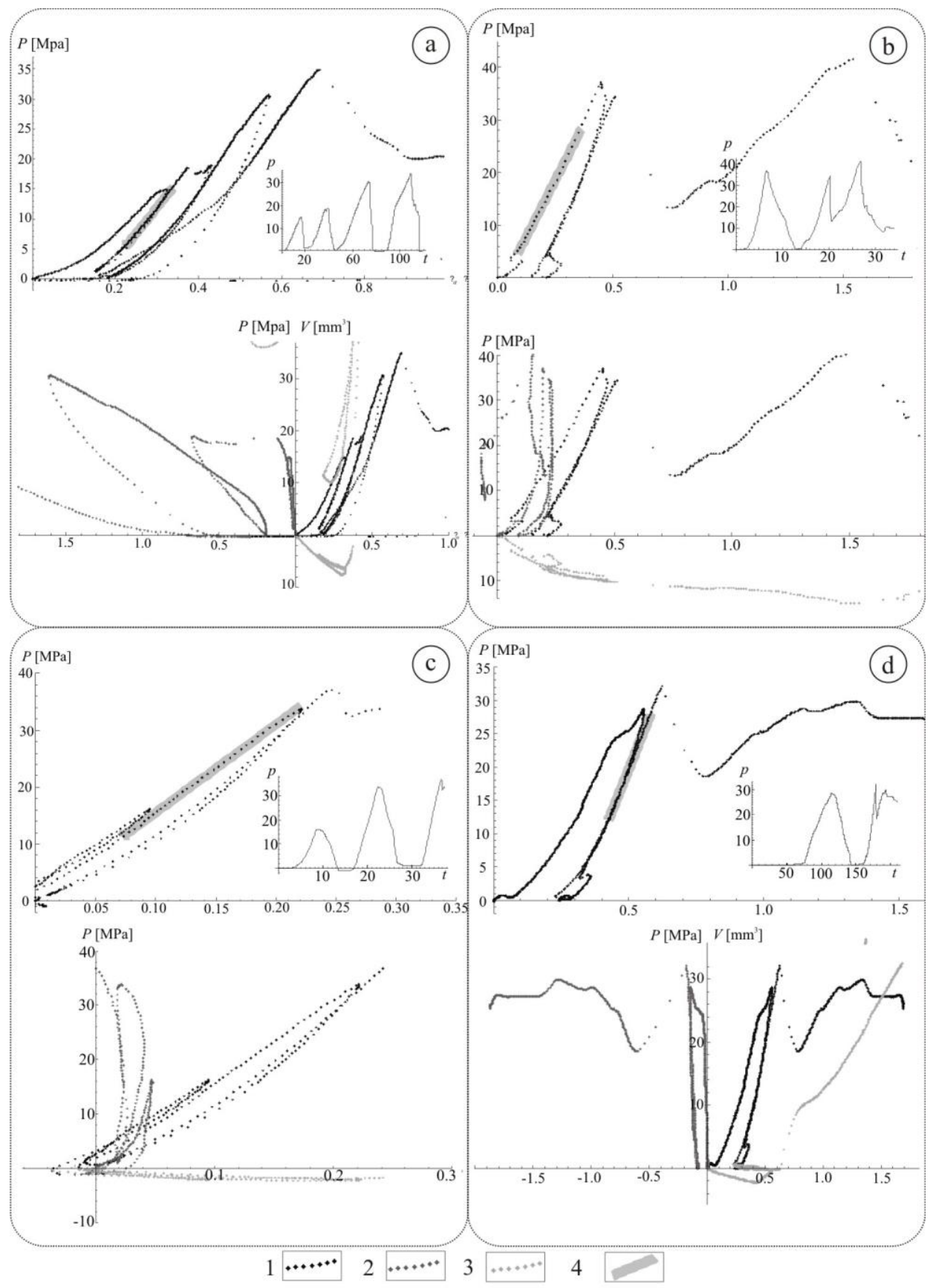

Figure 6. Characteristic stress-stain curves of: a) orthogneiss b) orthogneiss mylonite c) graphitic gneiss mylonite parallel, d) graphitic gneiss mylonite perpendicular. Legend: $1-3$ ) results of the measurements, 4) elastic line. 


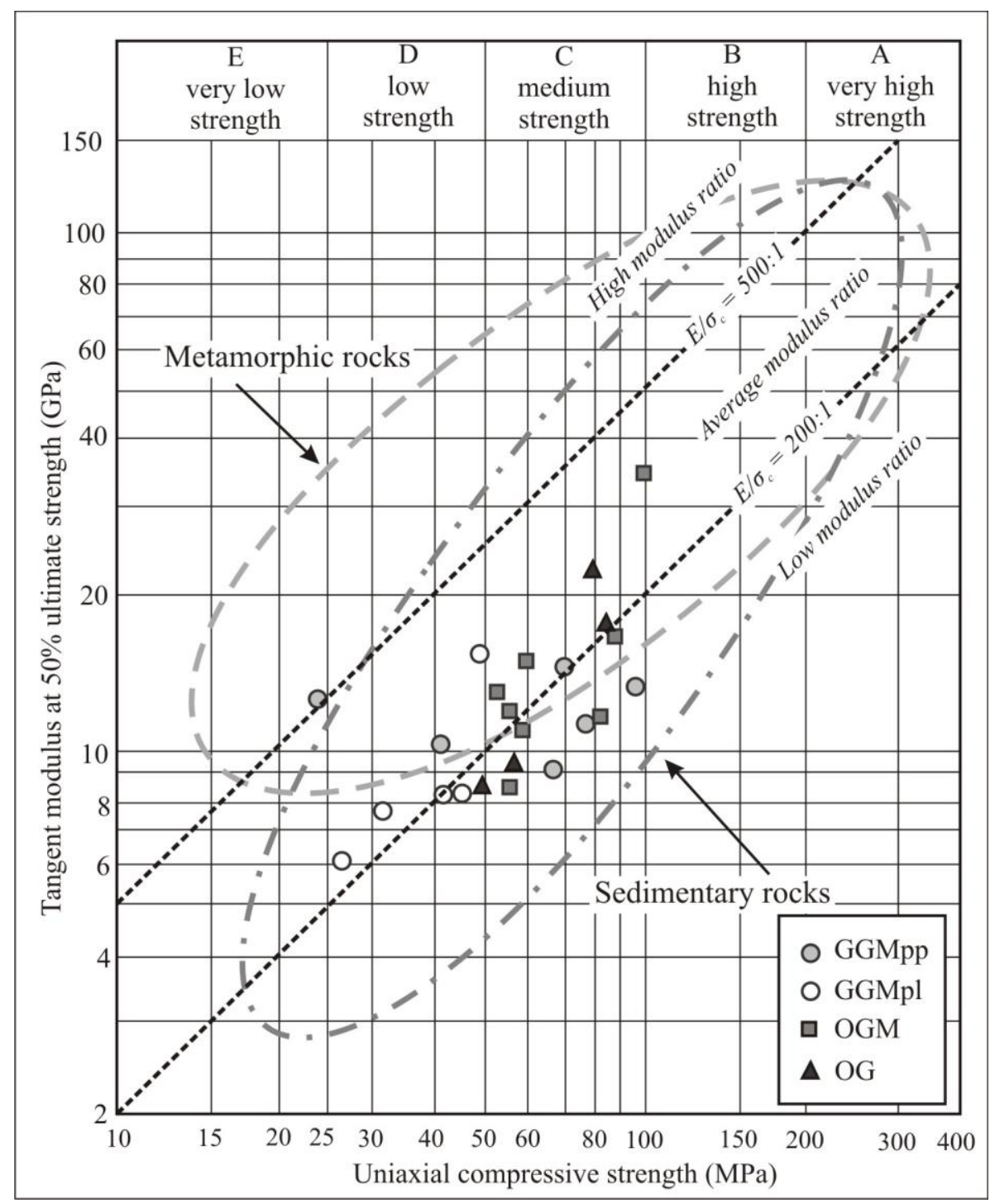

Figure 7. The concept of the Modulus Ratio (MR): a strength-deformation representation for rock materials and rock masses (Deere and Miller 1966) with the characteristic intervals of the metamorphic and sedimentary rocks. The KIHA-NE data were plotted $(n=22)$. 

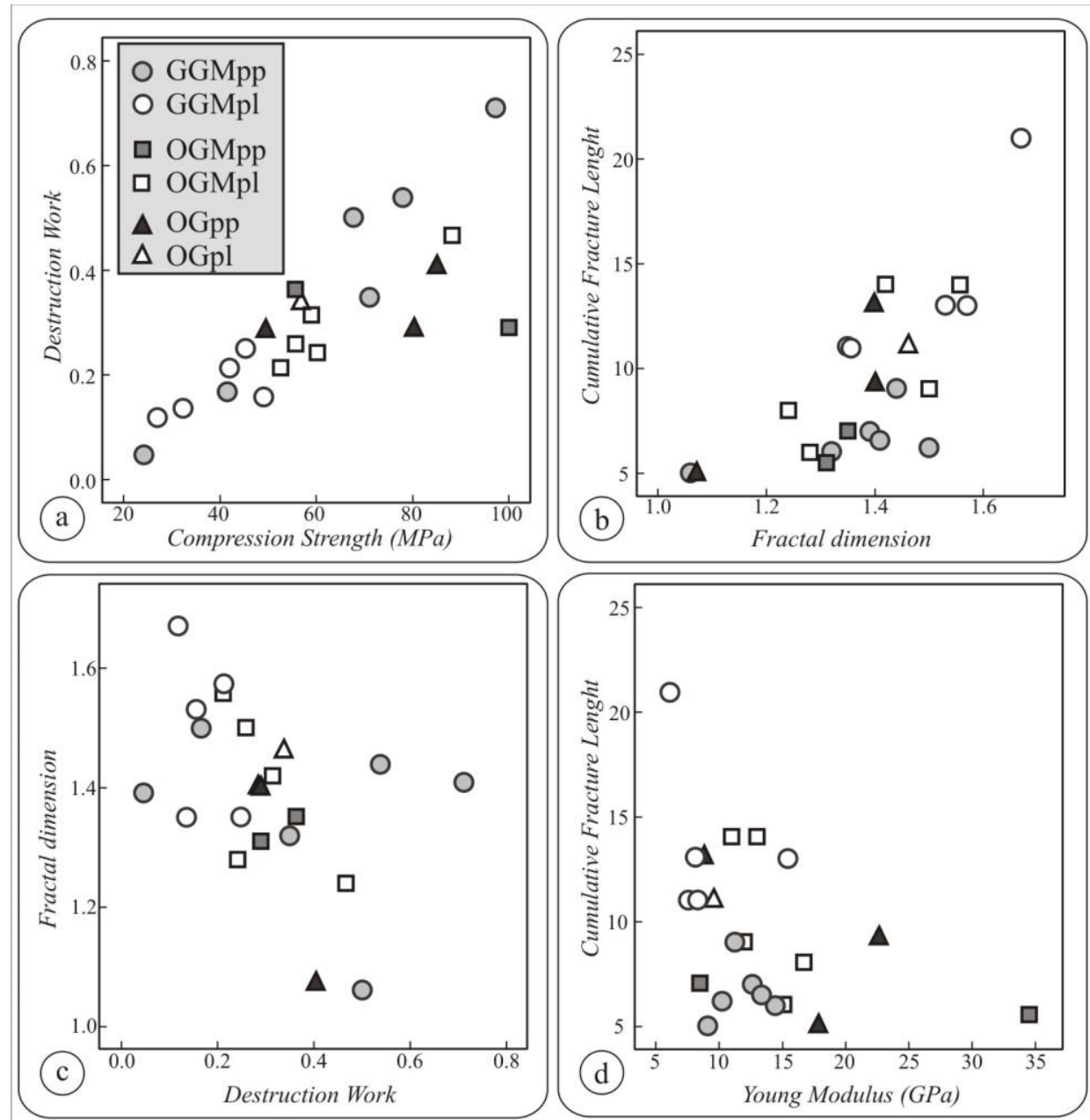

Figure. 8. Cross plots of KIHA-NE data $\left.\left.(n=22): a) W_{d}-\sigma_{c}, b\right) C F L-D, c\right) D-W_{d}$, d) CFL $-E$

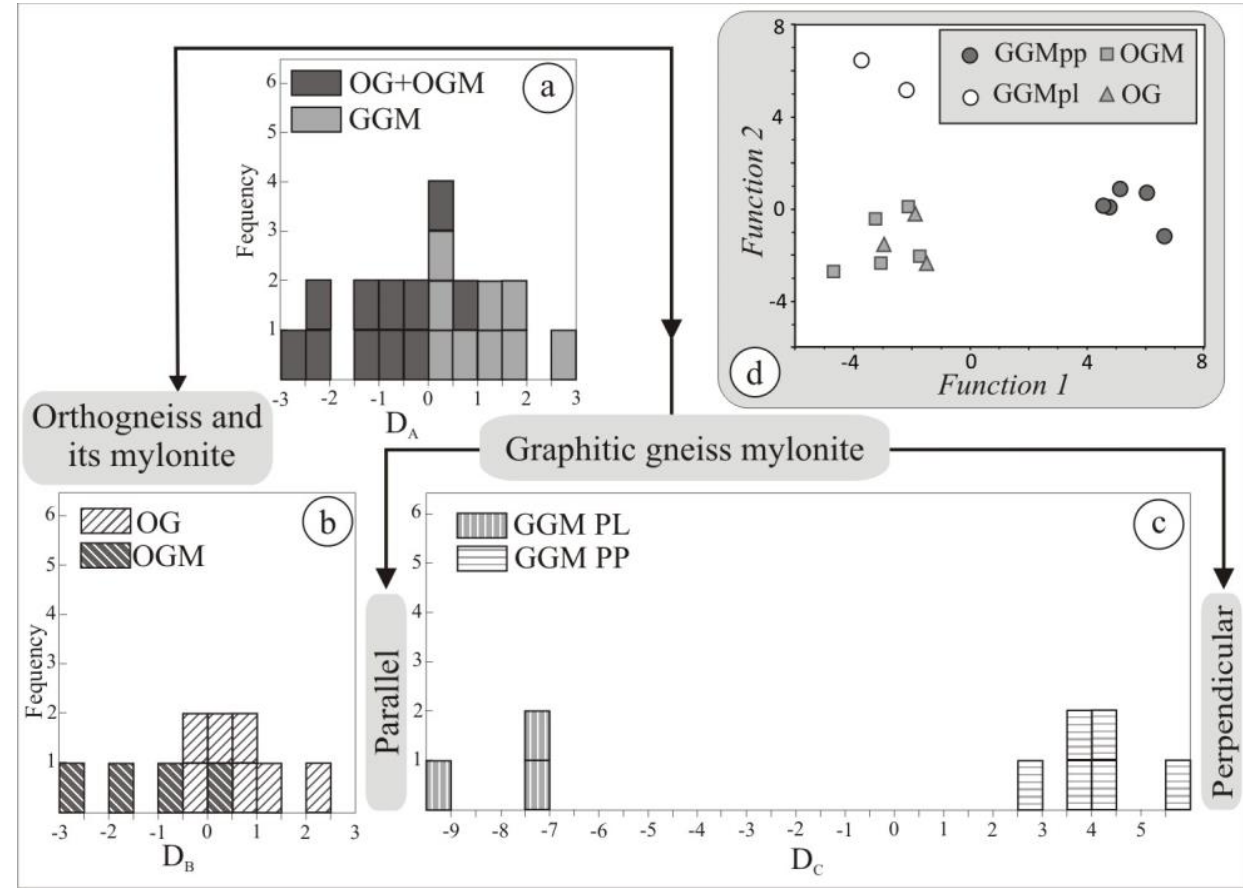

Figure. 9 Histograms of the discriminant scores for the lithology groups: a) orthogneiss (OG) with its mylonite (OGM) and graphitic gneiss mylonite $(\mathrm{GGM})$ b) orthogneiss $(\mathrm{OG})$ and orthogneiss mylonite (OGM) c) the parallel (PL) and the perpendicular (PP) graphitic gneiss mylonite (GGM) 